\title{
An electrochemical investigation of the corrosion behavior of Al-Si-Cu hypereutectic alloys in alcoholic environments
}

\author{
S.M. Traldi*, J.L. Rossi* and I. Costa*
}

\begin{abstract}
Al-Si-Cu hypereutetic alloys produced by spray forming are mostly used in the automotive industry, especially for cylinder liners. They have the advantage of low weight associated with low coefficient of thermal expansion and excellent mechanical properties - mainly wear resistance at high temperatures. The corrosion resistance of these alloys in fuels, particularly alcoholic media, however is not yet known. In this investigation, electrochemical impedance spectroscopy (EIS) and potentiodynamic polarisation have been used to evaluate the corrosion resistance of a hypereutectic $\mathrm{Al}-\mathrm{Si}-\mathrm{Cu}$ alloy in alcoholic environments. The EIS tests were carried out in pure ethanol, and ethanol with small additions $(1 \mathrm{mM})$ of acid and chloride, to investigate the effect of these contaminants on corrosion resistance. The corrosion resistance of a grey cast iron has also been evaluated in pure ethanol for comparison. The Al-Si-Cu alloy showed high corrosion resistance in pure ethanol, far superior to that of grey cast iron in the same medium.
\end{abstract}

Keywords Al-Si-Cu hypereutetic alloys. Alcoholic media. Corrosion. Spray forming.

\section{Una investigación electroquímica del comportamiento de corrosión de aleaciones hipereutécticas en medio alcohólico}

\begin{abstract}
Resumen Aleaciones hipereutécticas producidas por conformación por spray son muy empleadas en la industria automovilística, especialmente en los revestimientos de los cilindros. Tienen la ventaja de añadir menos peso con bajo coeficiente de expansión térmica y excelentes propiedades mecánicas, sobre todo resistencia al desgaste en altas temperaturas. Todavía, la resistencia a la corrosión de estas aleaciones en combustibles no es conocida. En este estudio fueron utilizadas las técnicas de espectroscopia de impedancia electroquímica y polarización potenciodinámica, para evaluar la resistencia a la corrosión de una aleación hipereutéctica $\mathrm{Al}-\mathrm{Si}$-Cu en medio alcohólico. Las pruebas fueron conducidas en etanol puro y etanol con pequeñas adiciones $(1 \mathrm{mM})$ de ácido y cloruro, con la finalidad de investigar el efecto de estos contaminantes en la resistencia a la corrosión. Hierro fundido gris, también fue evaluado en etanol puro para comparación de la resistencia a la corrosión. Las aleaciones $\mathrm{Al}-\mathrm{Si}-\mathrm{Cu}$ presentarán elevada resistencia a la corrosión en etanol puro, muy superior a la del hierro fundido gris en el mismo medio.
\end{abstract}

Palabras clave Aleaciones hipereutécticas Medio alcohólico. Conformación por spray.

\section{INTRODUCTION}

In the last few decades there has been significant growth in technological development of new materials, mainly related to improving products and technologies used in the production area in the automobile, aerospace and power sectors ${ }^{[1-3]}$.

The race among automobile manufacturers in turn has created increasing interest in materials with improved properties for new applications. In this sector, the properties most pursued are, reduced weight associated with low coefficient of thermal expansion, along with excellent mechanical properties, mainly abrasion resistance at high temperatures. In this context various new materials have been studied, and the high performance aluminium alloys have drawn a lot of interest, mainly the Al-Li and Al-Si alloys.

Among the Al-Si alloys, the ones with hypereutectic compositions have been found to be more interesting as they have optimum properties in terms of abrasion resistance. This is because of the large volumetric fraction of the primary silicon phase $\mathrm{p}^{[1,2 \text { and } 4-6]}$. However, in spite of the optimum properties, it was only with technological advances

$\left({ }^{*}\right)$ Instituto de Pesquisas Energéticas e Nucleares-IPEN. P.O. Box 11049, Pinheiros. CEP 05422-970, São Paulo-Brazil. 
enabled by spray forming that they could be optimised $^{[7]}$. Spray forming permits the production of hypereutectic Al-Si alloys with a fine and homogeneous distribution of primary silicon. In this manner, the manufacture of industrial components such as cylinder liners has been made possible with various advantages such as weight reduction, decrease in emission of exhaust gases and savings in fuel ${ }^{[8]}$.

In the last few decades, along with technological advances, concerns about environmental pollution caused by exhaust gases from petroleum fuel driven cars have increased in the automotive industry. This was due mainly to significant increase in the number of automobiles in large cities.

Advances in pollution control technologies have been significant, but not sufficient to reduce the problems of environmental pollution. Research on alternate sources of energy for traction increased rapidly, both in terms of old options such as alcohol's in the form of methanol and fuel alcohol, as well as in other fuels such as natural gas, hydrogen and the use of electric energy.

In Brazil, in the 70s and early 80s, there were significant efforts and attempts to resolve corrosion problems created by fuel alcohol on automobile components ${ }^{[5}$ and $\left.9-12\right]$. Even though most of the corrosion problems were solved, as a result of this effort, various aspects of corrosion in alcoholic media, especially those related to mechanism and the effects of impurities present in the fuels have not yet been resolved. The behaviour of new materials, subsequently developed in the $90 \mathrm{~s}$, in these corrosive media is as yet unknown.

The aim of this investigation was to determine the corrosion behaviour of a hypereutectic Al-Si$\mathrm{Cu}-\mathrm{Mg}$ alloy obtained by spray forming, in alcoholic media, both pure and containing small amounts of contaminants. This alloy is used in automobile engine cylinder liners. The contaminants of fuel alcohol studied in this investigation were chlorides and acids. Another aim of this study was to compare the behaviour of this alloy with that of grey cast iron, an alloy widely used as cylinder liners in alcoholic media.

\section{EXPERIMENTAL PROCEDURE}

\subsection{Materials}

The materials studied were an Al-Si hypereutectic alloy, and grey cast iron. Their compositions are given in tables I and II respectively. The test environments used in this investigation were pure ethanol, pure ethanol with addition of sulphuric acid $(1 \mathrm{mM})$, and pure ethanol with addition of analytical grade $(A G)$ lithium chloride $(1 \mathrm{mM})$.

\subsection{Methods}

The methods used to investigate corrosion behaviour were electrochemical impedance spectroscopy and potentiodynamic polarisation. To carry out the impedance tests, a Solartron frequency response analyser coupled to an $E G \& G$ PARC potentiostat were used and controlled with appropriate software. To carry out the potentiodynamic polarisation tests an $E G \& G$ PARC potentiostat was used with a proper software that permitted ohmic drop compensation.

The potential amplitude applied in the electrochemical impedance test was $20 \mathrm{mV}$ and the frequency range varied from $10^{2} \mathrm{~Hz}$ to $10^{-2} \mathrm{~Hz}$. The polarisation tests were carried out from -500 $\mathrm{mV}$, with respect to the corrosion potential, up to $+1500 \mathrm{mV}$ vs the reference electrode $(\mathrm{Ag} / \mathrm{AgCl} / \mathrm{KCl}$ sat $)$. All the tests were carried out

Table I. Composition of hypereutectic Al-Si-Cu-Mg alloy

Tabla I. Composición de las aleaciones hipereutécnicas de Al-Si-Cu-Mg

Composition (\% wt)

Al $\mathrm{Si} \mathrm{Cu} \mathrm{Mg} \mathrm{Ni}$ Fe Others

Al-Si-Cu-Mg Alloy $\begin{array}{lllllll}71.90 & 23.16 & 2.70 & 1.00 & 0.96 & 0.19 & 0.09\end{array}$

Table II. Composition of grey cast iron

Tabla II. Composición del hierro fundido gris

\begin{tabular}{ccccccccccccc}
\hline & \multicolumn{11}{c}{ Composition (\% wt) } \\
\hline \multirow{3}{*}{ Grey Cast Iron } & $\mathrm{Fe}$ & $\mathrm{C}$ & $\mathrm{Si}$ & $\mathrm{Mn}$ & $\mathrm{Cr}$ & $\mathrm{Cu}$ & $\mathrm{Mo}$ & $\mathrm{Ni}$ & $\mathrm{P}$ & $\mathrm{S}$ & $\mathrm{Mg}$ \\
& 92.65 & 3.05 & 2.11 & 0.62 & 0.61 & 0.51 & 0.13 & 0.12 & 0.11 & 0.087 & 0.004 \\
\hline
\end{tabular}


after one day of immersion of the specimens in the different media at room temperature and the media were deaerated.

\section{RESULTS}

Figure 1 shows the results of the electrochemical impedance tests on $\mathrm{Al}-\mathrm{Si}-\mathrm{Cu}-\mathrm{Mg}$ in pure ethanol. The data obtained were modelled and the equivalent circuit that best fitted to the results is shown in figure 2.

In figure $2, \mathrm{Rs}_{1}$ represents the ohmic resistance of the electrolyte. $\mathrm{R}_{\mathrm{ox}}$ and $\mathrm{C}_{\mathrm{ox}}$ are the resistance and capacitance components of the oxide on the alloy surface, which was porous, permitting access of the corrosive medium to the metallic surface. $\mathrm{Rct}_{1}$ and $\mathrm{Cdl}_{1}$ are the charge transfer resistance and electrical double layer capacitance respectively, which correspond to the Faradaic process at the alloy/alcoholic medium interface.

Figure 3 shows the Nyquist diagrams of the alloy $\mathrm{Al}-\mathrm{Si}-\mathrm{Cu}-\mathrm{Mg}$ in the two media, ethanol with addition of acid and ethanol with addition of chloride. The impedance results shown in figure 3 were fitted to give the equivalent circuits shown in figure 4 . In these circuits, $\mathrm{Rs}_{2}$ and $\mathrm{Rs}_{3}$ represent the ohmic resistance in the respective media. $\mathrm{Rct}_{2}$ and $\mathrm{Cdl}_{2}$ are the charge transfer resistance and electrical double layer capacitance respectively, related to the Faradaic process at the alloy/media interface. Rct $_{\text {cat }}$ is the charge transfer resistance of the cathodic reaction and $\mathrm{Rw}_{2}$ represents the

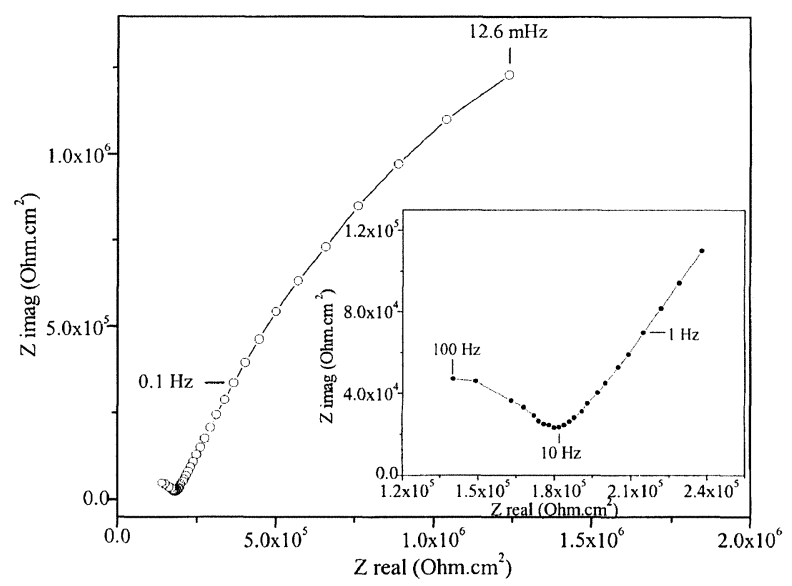

Figure 1. Nyquist diagram of alloy $\mathrm{Al}-\mathrm{Si}-\mathrm{Cu}-\mathrm{Mg}$ in $\mathrm{AG}$ ethanol showing data in: (a) whole frequency range and (b) high frequency region.

Figura 1. Diagrama de Nyquist de la aleación Al-Si-Cu-Mg en etanol $A G$ presentando los datos en: (a) intervalo de frecuencia total; (b) región de alta frecuencia.

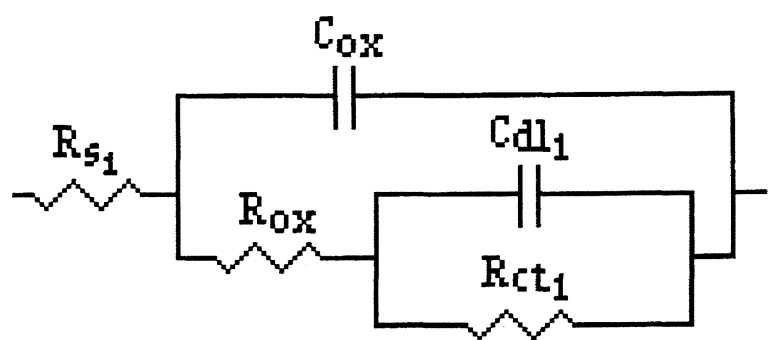

Figure 2. Equivalent circuit related to data presented in figure 1, where $R s_{1}=6.7 \times 10^{3} \Omega . \mathrm{cm}^{2}, R_{o x}=4.4 \times 10^{4} \Omega . \mathrm{cm}^{2}$, $\mathrm{C}_{\mathrm{ox}}=8.9 \times 10^{-8} \mathrm{~F}_{\mathrm{cm}}{ }^{-2}, \mathrm{Rct}_{1}=1.4 \times 10^{6} \Omega . \mathrm{cm}^{2}, \mathrm{Cdl}_{1}=$ $1.3 \times 10^{-5} \mathrm{~F}_{\mathrm{cm}} \mathrm{cm}^{-2}$

Figura 2. Circuito equivalente relativo a los datos presentados en la figura 1 , donde $R_{s 1}=6,7 \times 10^{3} \Omega . \mathrm{cm}^{2}$, $R_{\text {ox }}=4,4 \times 10^{4} \Omega . \mathrm{cm}^{2}, \quad C_{\text {ox }}=8,9 \times 10^{-8} \mathrm{~F}_{\mathrm{cm}}{ }^{-2}, \quad \mathrm{Rct}_{1}=$ $1,4 \times 10^{6} \Omega . \mathrm{cm}^{2}, \mathrm{Cdl}_{1}=1,3 \times 10^{-5} \mathrm{~F}_{\mathrm{cm}}$.

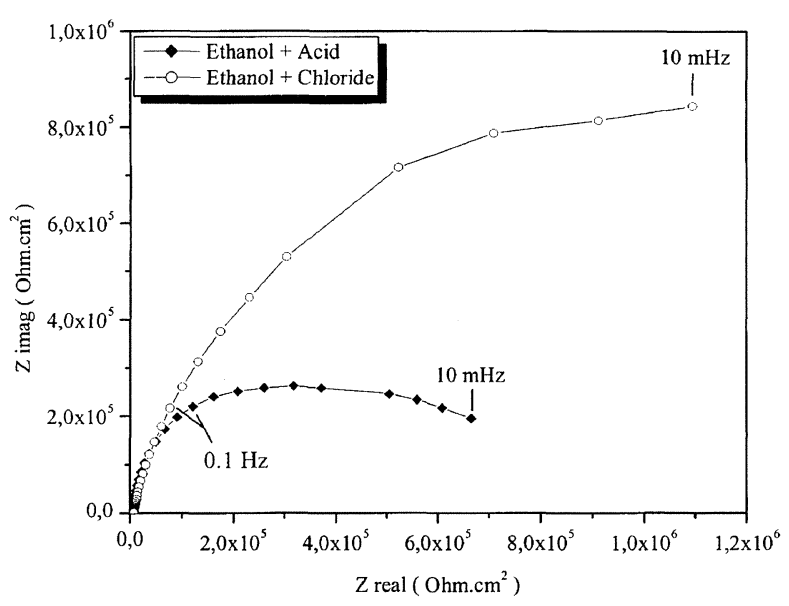

Figure 3. Nyquist diagrams of alloy $\mathrm{Al}-\mathrm{Si}-\mathrm{Cu}-\mathrm{Mg}$ in ethanol media with small additions (1 $\mathrm{mM}$ ) of acid and chloride.

Figura 3. Diagrama de Nyquist de la aleación Al-Si-Cu-Mg en medio de etanol con pequeñas adiciones $(1 \mathrm{mM})$ de ácido y cloruro.

Warburg impedance related to mass transport of the reactive species to the surface. The results indicate that the cathodic reaction was diffusion controlled.

The addition of acid to pure alcohol apparently resulted in dissolution of oxide on the metallic surface, besides impeding the formation of oxide in this test environment. This was revealed in the electrochemical impedance results, where there was only the response corresponding to the metal/environment interface.

In the alcohol environment with chloride additions, the impedance response is typical of that which occurs in localized corrosion, where $R_{\text {pass }}$ and $\mathrm{C}_{\text {pass }}$ are the passive surface resistance and 


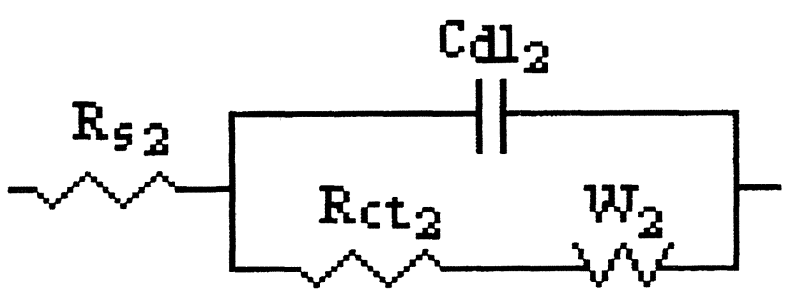

(a)

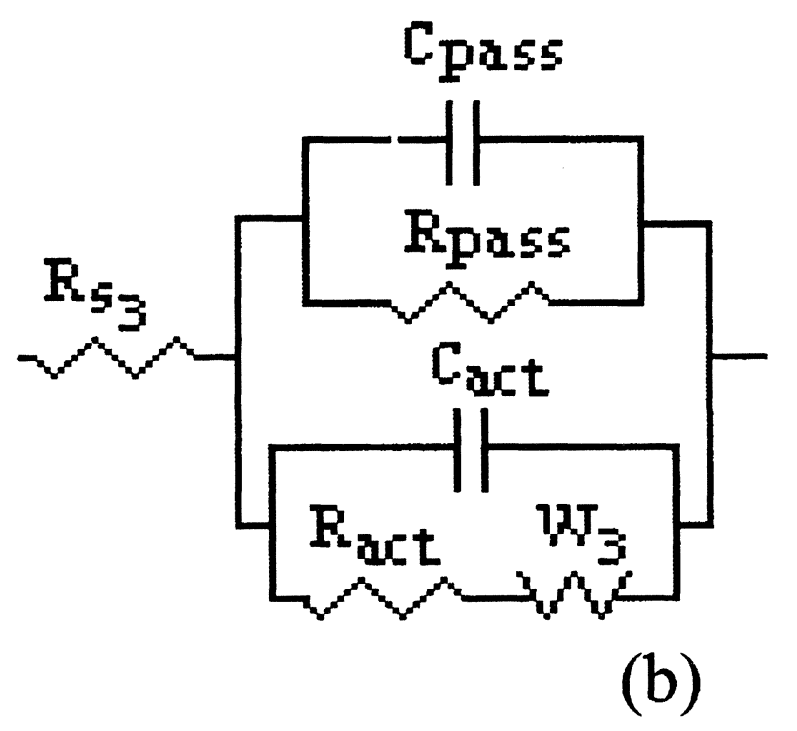

Figure 4. Equivalent circuits related to data shown in figure 3 in alcohol media with additions of: (a) acid (1 $\mathrm{mM})$, where $\mathrm{Rs}_{2}=940 \Omega . \mathrm{cm}^{2}, \mathrm{Rct}_{2}=9.5 \times 10^{3} \Omega . \mathrm{cm}^{2}, \mathrm{Cdl}_{2}=1.93 \times 10^{-5}$ F.cm ${ }^{-2}$, and $W_{2}=2.48 \times 10^{5} \Omega / \mathrm{s}$ and $(b)^{\prime}$ chloride $(1 \mathrm{mM})$, where $R_{s}=1732 \Omega . \mathrm{cm}^{2}, R_{\text {pass }}=5.4 \times 10^{5} \Omega . \mathrm{cm}^{2}, C_{\text {pass }}=$ $3.3 \times 10^{-6}{\mathrm{~F} . \mathrm{cm}^{-2}}, \mathrm{R}_{\mathrm{act}}=5.4 \times 10^{-3} \Omega . \mathrm{cm}^{2}, \mathrm{C}_{\mathrm{act}}=3.59 \times 10^{-6}$ F.cm ${ }^{-2}$ and $W_{3}=1.95 \times 10^{3} \Omega / \mathrm{s}$.

Figura 4. Circuito equivalente relativo a los datos presentados en la figura 3, en medio alcohólico, con adiciones de: (a) ácido $(1 \mathrm{mM})$, donde $R s_{2}=940 \Omega . \mathrm{cm}^{2}$, $\mathrm{Rct}_{2}=9,5 \times 10^{3} \Omega \mathrm{Ccm}^{2}, \mathrm{Cdl}_{2}=1,93 \times 10^{-5}{\mathrm{~F} . \mathrm{cm}^{-2} \text { y W }}_{2}=2,48$ $\times 10^{5} \Omega / \mathrm{s}$ y (b) cloruro $(1 \mathrm{mM})$, donde $R s_{3}=1732 \Omega . \mathrm{cm}^{2}$, $R_{\text {pass }}=5,4 \times 10^{5} \Omega . \mathrm{cm}^{2}, C_{\text {pass }}=3,3 \times 10^{-6} \mathrm{~F}_{\mathrm{cm}} \mathrm{cm}^{-2}, R_{\mathrm{act}}=5,4 \times$ $10^{-3} \Omega . \mathrm{cm}^{2}, C_{a c t}=3,59 \times 10^{-6} \mathrm{~F}_{\mathrm{cm}} \mathrm{cm}^{-2}$ y $W_{3}=1,95 \times 10^{3} \Omega / \mathrm{s}$.

capacitance respectively, whereas $R_{\text {act }}, C_{\text {act }}$, and $\mathrm{W}_{3}$, are related to reactions in the active region. The data obtained indicate that the corrosion process was diffusion controlled, due probably to oxygen transport in the direction of the metal/oxide interface and aluminium ions away from the active metal interface.

The potentiodynamic polarisation curves of the $\mathrm{Al}-\mathrm{Si}-\mathrm{Cu}-\mathrm{Mg}$ alloy and the grey cast iron in pure ethanol and ethanol with acid additions (1mM) are shown in figure 5 . These curves permit comparison of the behaviour of these two materials. In figure 5, in ethanol and ethanol with acid additions, the aluminium alloy shows much lower corrosion rates, compared to the grey cast iron. This occurred mainly in pure ethanol, where the corrosion rate of cast iron was around $10^{3}$ times higher than that of the aluminium alloy. The corrosion rate of the aluminium alloy in pure ethanol is very low, indicating passivity. However, a behaviour typical of an active metal during anodic polarisation can be observed. The anodic
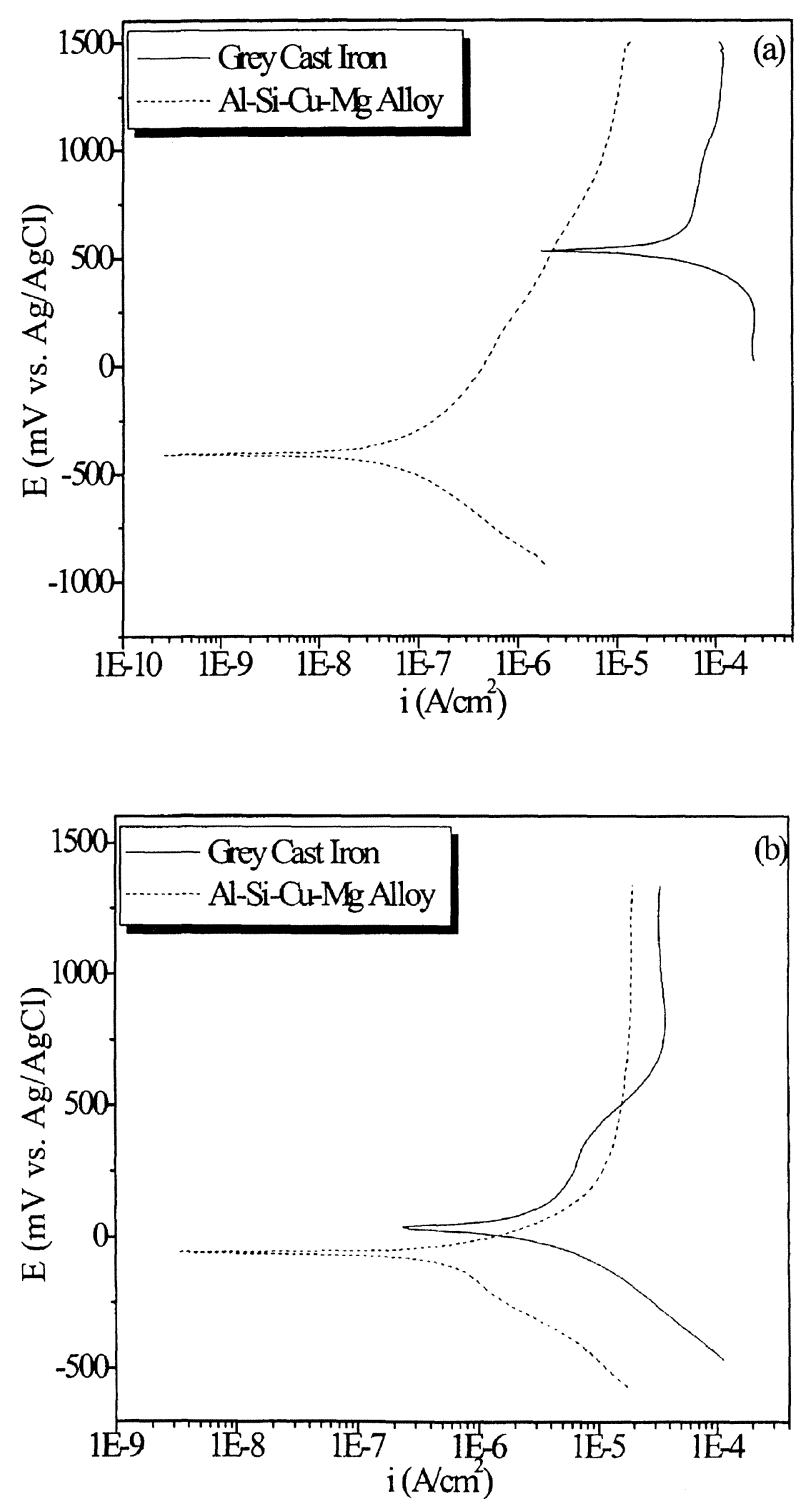

Figure 5. Potentiodynamic polarization curves of grey cast iron and Al-Si-Cu-Mg alloy in: (a) AG ethanol media; (b) Ethanol media with addition of $1 \mathrm{mM}$ acid.

Figura 5. Curvas de polarización potenciodinámica del hierro fundido gris y aleación Al-Si-Cu-Mg en: (a) medio de etanol AG, (b) medio de etanol con adición de $1 \mathrm{mM}$ de ácido. 
Tafel slope was however very high compared to that of typical slopes in aqueous media. This apparently is a characteristic of alcoholic media. The large slopes indicate the presence of a film on the surface of the specimen, partially permeable and obstructing the metal dissolution reaction, but permitting an electrochemical reaction to occur. According to Fernandes and Ferreira ${ }^{[13]}$, the surface oxide on aluminium permits the movement of ionic species and electron or vacancy flux across it.

Figure 6 shows the effect of acid addition on the corrosion behaviour of the two materials. The corrosion rate of the alloy increased ten times after addition of acid. This was probably due to dissolution of the surface oxide. This result supports the electrochemical impedance data, which also suggested dissolution of the surface oxide.

The addition of acid to the alcohol also seemed to have caused depolarisation of the cathodic reaction by favouring the cathodic hydrogen evolution reaction.

\section{CONCLUSIONS}

The electrochemical impedance technique has been found to be appropriate to investigate the corrosion behaviour of $\mathrm{Al}-\mathrm{Si}-\mathrm{Cu}$ alloy in alcoholic media, enabling the effect of addition of small amounts of contaminants to ethanol to be observed. In pure alcohol the impedance results

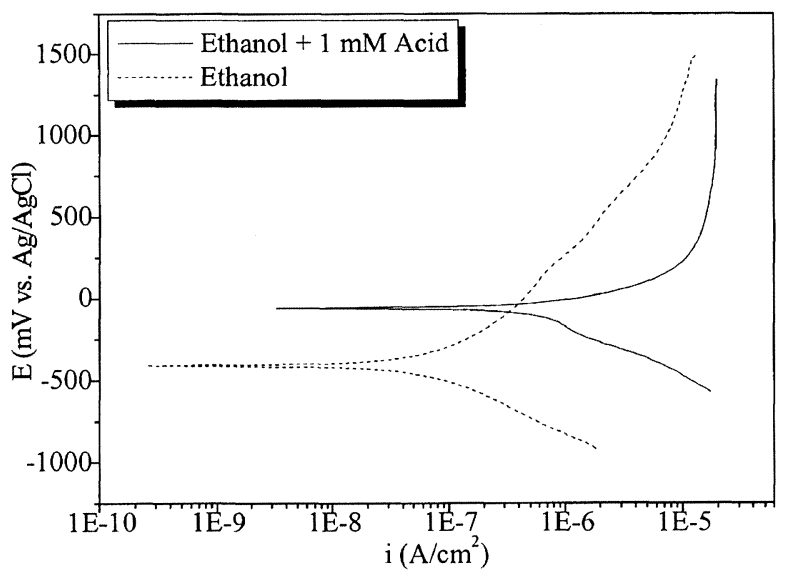

Figure 6. Potentiodynamic polarization curves of Al-Si-Cu$\mathrm{Mg}$ alloy in pure ethanol and in ethanol with addition of acid.

Figura 6. Curvas de polarización potenciodinámica de la aleación Al-Si-Cu-Mg en medio de etanol puro y en etanol con adición de ácido. indicate the presence of a surface oxide and the polarisation results indicate this oxide to be at least partially permeable. The results also indicated that the addition of acid to alcohol, even in small quantities, causes dissolution of the initial oxide present on the surface and impedes its formation when immersed in the environment. The impedance data of the alloy immersed in environments containing chlorides were characteristic of localised corrosion. The Al-Si$\mathrm{Cu}-\mathrm{Mg}$ alloy showed higher corrosion resistance than grey cast iron in pure ethanol and acid containing ethanol.

\section{Acknowledgements}

The authors wish to thank FAPESP for the financial support given for carrying out this project.

\section{REFERENCES}

[1] F. Yilmaz and R. Elliot, J. Mater. Sci. 246 (1989) 2065 2070.

[2] J. Zhou, J. Duszczyk and B.M. Korovaar, J. Mater. Sci. 2611 (1991) 3041-3050.

[3] J.T. Staley and D.J. Lege, Journal of Physique IV Colloque C7, supplément au Journal de Physique III, 3 (November), 1993, pp. 179-190.

[4] J.L. Estrada, F. Juarez and E.J. Lavernia, Adv. Powder Metall.Part. Mater. 1 (1997) 61-70.

[5] P. Stocker, F. Ruckert and K. Hummert, MTZ Motortech. Z. 589 (1997)16-19.

[6] J.L. Estrada and J. Duszczyk, J. Mater. Sci. 25 (1990) 1381-1391.

[7] M. Motomura, T. Haga and Y. Sakurai, J. Japan Inst. Light Metals 38 (1988) 528-534.

[8] S. Wolynec, Proc. 10 th Brazilian Corrosion Seminar, Rio de Janeiro, RJ, 1983, pp. 17-31 (In Portuguese).

[9] Z.P. Kajimoto and S. Wolynec, Proc. $3^{\text {rd }}$ Brazilian Surface Treatment Meeting, São Paulo, SP,1983, pp. 263-283 (In Portuguese).

[10] D.K. TANAKa and S. Wolynec, Proc. $9^{\text {th }}$ Brazilian Corrosion Seminar, Rio de Janeiro, RJ, 1982, p. 166-176 (In Portuguese)..

[11] V.G. Wanderley, S. Bastos, S. WeXler and L. Uller, Proc $9^{\text {th }}$ Brazilian Corrosion Seminar, Rio de Janeiro, RJ, 1982, pp. 369-382 (In Portuguese).

[12] R.O. Vianna and H.A.A.A. Rehim, Proc. 10th Brazilian Corrosion Seminar, Rio de Janeiro, RJ,1983, pp. 86-98 (In Portuguese).

[13] C.S. Fernades and M.G.S. Ferreira, Proc. EIS 98, Rio de Janeiro, RJ, 1998, pp. 112-114. 